\title{
The effects of Biofreeze and superficial heat on masticatory myofascial pain syndrome
}

\section{Purpose}

This study aims to assess the influence of superficial heat and Biofreeze on pain, mouth opening $(\mathrm{mm})$, and quality of life in patients with masticatory myofascial pain syndrome (MPS).

\section{Materials and Methods}

52 patients with MPS were included in the study. They were randomly divided into two groups. Patients in the Biofreeze group $(n=26)$ applied 3.5\% menthol gel to the masseter and temporal muscles twice a day for seven days, while the other group applied superficial heat. Baseline, $7^{\text {th }}$, and $21^{\text {st }}$ days of VAS, mouth opening $(\mathrm{mm})$, and Oral Health Impact Profile-14 (OHIP-14) scores of the patients were evaluated statistically.

\section{Results}

The mouth opening increased by $4.27 \pm 3.80 \mathrm{~mm}$ in the Biofreeze group and 2.58 $\pm 2.16 \mathrm{~mm}$ in the superficial heat group. In each group, a significant decrease in VAS and OHIP-14 scores was observed on the $7^{\text {th }}$ day compared to the baseline values $(p<0.001)$. There was no statistically significant difference between the two applications on myofascial pain, mouth opening $(\mathrm{mm})$, and OHIP-14 total score variables. The favorable effects of both applications on these parameters were limited to the duration of use.

\section{Conclusion}

Biofreeze and superficial heat in MPS were found to increase the quality of life, but the limited effectiveness of these applications underlines the importance of the underlying factors.

Keywords: Myofascial pain, myofascial pain syndromes, myofascial trigger point pain, menthol, referred pain

\section{Introduction}

Masticatory myofascial pain syndrome (MPS) is characterized by the presence of trigger points that cause local and referred pain in associated structures, such as the teeth and temporomandibular joint (TMJ) (1). Previously, myofascial trigger points were detected in $55.4 \%$ of patients who presented to dental clinics for the treatment of chronic head and neck pain, highlighting the wide distribution of MPS (2). Clinically, the restriction of mandibular movements secondary to pain, facial asymmetry, difficulty speaking, vertigo, and tinnitus are common symptoms (3). Several factors, such as sudden muscle loading or chronic injury due to recurrent microtraumas, genetic factors, and stress, contribute to MPS development (4). Treatment strategies aim to relieve pain by inactivating trigger points, relieving local muscle spasms, normalizing the muscle length, and improving functional capacity (5). Local anesthetic/botulinum toxin injections, acupuncture, transcutaneous electrical nerve stimulation (TENS),

\author{
Deniz Yaman' ${ }^{1}$, \\ Cansu Alpaslan² ${ }^{\text {iD, }}$ \\ Oya Kalaycıoğlu ${ }^{3}$ iD
}

ORCID IDs of the authors: D.Y. 0000-0002-1492-6897; C.A. 0000-0003-2092-7842; O.K. 0000-0003-2183-7080

'Department of Oral and Maxillofacial Surgery, Faculty of Dentistry, Bolu Abant Izzet Baysal University, Bolu, Turkey

${ }^{2}$ Department of Oral and Maxillofacial Surgery, Faculty of Dentistry, Gazi University, Ankara, Turkey

${ }^{3}$ Department of Biostatistics and Medical Informatics, Faculty of Medicine, Bolu Abant Izzet Baysal University, Bolu, Turkey

Corresponding Author: Deniz Yaman E-mail:yamand896@gmail.com

Received: 12 January 2021 Revised: 9 February 2021 Accepted: 24 March 2021

DOI: 10.26650/eor.2021858837 
ultrasound, superficial heat, massage, cold compression applied to the trigger point, and pharmacological agents are frequently preferred treatment methods (5).

Superficial heat is widely used to increase blood pressure and tissue perfusion as well as to reduce neuropathic pain and joint stiffness (6). It can be applied at home using a variety of methods. This is one of the advantages of superficial heat, which makes it a commonly preferred treatment approach for MPS $(6,7)$. However, the use of alternative agents to relieve pain has become increasingly popular $(8,9)$. Menthol, one of the primary active ingredients in Biofreeze, has been shown to control pain through the stimulation of cold receptors within the opioid or glutamate systems (10). Unlike traditional cold applications, Biofreeze exerts cryotherapeutic effects by blocking sodium channels, which creates a cooling sensation without actively decreasing overall skin temperature, increasing the topical analgesic effects of menthol $(11,12)$. Menthol reduces blood flow and causes vasoconstriction, similar to the outcome observed with ice application (13). However, the isopropyl alcohol and glycerin contained in Biofreeze have also been shown to exert vasodilation effects $(14,15)$. Due to the contradictory nature of these substances, we aimed to investigate the effects of Biofreeze on MPS. To our best knowledge, no previous studies have explored the effects of superficial heat and Biofreeze on the outcomes of pain, mouth opening (measured in $\mathrm{mm}$ ), and quality of life among patients with MPS. Therefore, we have tested the null hypothesis that no statistically significant difference would be found between Biofreeze and superficial heat in terms of inhibiting the pain associated with MPS by preventing the formation of trigger points. This study also aimed to determine the short and long-term effects of these two applications when used in patients with MPS.

\section{Materials and Methods}

\section{Ethical statement}

The research was approved by the Local Ethics Committee (No:2015/118), and all participants signed a consent form before the start of the study. The study was carried out compatible with the Declaration of Helsinki.

\section{Sample size estimation}

A priori power analysis was performed based on the repeated measures ANOVA with three-time points using the software $G^{*}$ power version 3.1.9.4 (18). A sample size of 52 was found to be adequate to detect a difference in terms of the effect size of $\mathrm{f}=0.25$ with $80 \%$ statistical power at $\mathrm{a}=0.05$.

\section{Patient selection}

A total of 52 patients ( 45 females and 7 males) who were diagnosed with MPS and have no history of occlusal splint usage were included in the study. The patients were divided into 2 groups: the first group received Biofreeze $(n=26)$ while the second one superficial heat treatment $(n=26)$. The inclusion criteria were chronic unilateral pain longer than 3 months and referred pain distributed from myofascial trigger points in the masseter and temporalis muscles to the face, mouth, or TMJ. These inclusion criteria for MPS are consistent with the guidelines of the American Academy of Orofacial Pain and the Research Diagnostic Criteria for TMD (RDC/ TMD) (7). In clinical examination, any tooth or maxillofacial lesions that could be the source of the pain were excluded. Radiographic imaging of the temporomandibular joint was performed to rule out disc displacement, effusion, degenerative disorders. Patients with trigeminal neuralgia, head and neck inflammation, endocrine diseases, and those using oral contraceptive drugs, and those with skin lesions (scar tissue, skin graft) on the treatment area were excluded from the study. The presence of hard, palpable nodules in the masseter and temporalis muscles, indicating the active myofascial trigger points, was the common feature of all patients in this study. By bilateral manual palpation, pain in the muscles was recorded using the visual analog scale (VAS).

\section{Administration of Biofreeze and superficial heat}

The patients were divided into two groups randomly. In the Biofreeze group, the patients applied 3.5\% menthol gel to the masseter and temporal muscles twice a day for seven days. Patients were informed about the correct application of Biofreeze gel and a marked applicator strip was given to each patient to apply with a standard dose. Patients were told to massage the area with circular movements for about 30 seconds to 1 minute to allow the Biofreeze gel to penetrate under the skin. The remaining half of the patients applied superficial heat to the painful muscle areas twice a day for seven days. In this study, superficial moist heat application was done with a towel soaked in hot water $\left(212^{\circ} \mathrm{F}\right)$. In this group, each cycle was repeated for 10 minutes and paused for 5 minutes. After three 10-minute heat cycles, with two 5-minute pauses, the superficial heat application took 40 minutes. Since the adipose tissue on the face is not as dense as the other tissues of the body, 5-minute pauses were given to ensure tissue safety against the rapidly rising heat. No application was applied to all patients after the $7^{\text {th }}$ day.

\section{Recording of the clinical data}

VAS, mouth opening $(\mathrm{mm})$, and Oral Health Impact Profile-14 (OHIP-14) scores of the patients were compared at baseline, $7^{\text {th }}$, and $21^{\text {st }}$ days. The unassisted (mandibular) opening without pain and maximum assisted (mandibular) opening of the patients were measured using a millimeter ruler between the edges of the upper and lower middle incisors. The current study assessed the patients' functional limitation, physical pain, psychological discomfort, physical/ psychological/social incapacity, and social disadvantage with the OHIP-14 and compare the effects of these two applications at baseline, $7^{\text {th }}$, and $21^{\text {st }}$ days. The OHIP, originally consisting of 49 questions, uses the World Health Organization (WHO) International Classification of Impairments, Disabilities and Handicaps framework (16). However, OHIP14 is a shorter, patient-friendly version and consists of 14 questions. The previously validated Turkish translation of the OHIP-14 scale was used in this study. This scale scored between " 0 " and " 4 ". An increase in the OHIP-14 score indicates the severity of the current problem and a decline in quality of life (17). 


\section{Statistical analysis}

Data was evaluated by using Statistical Package for Social Science (SPSS Statistics for Windows, Version 25.0 Armonk, NY: IBM Corp, USA). The effects of the two different applications on the unassisted (mandibular) opening without pain and maximum assisted (mandibular) opening, VAS, and OHIP-14 score over time were compared with two-way repeated-measures ANOVA. The differences between the time points for each treatment group were further evaluated using the one-way repeated measures ANOVA followed by Bonferroni post-hoc multiple comparison tests. The confidence interval was set to $95 \%$ and $p$ values less than 0.05 were considered statistically significant.

\section{Results}

A total of 52 patients with MPS (86.5\% females, $13.5 \%$ males; age range: $18-50$ years; mean age: $36.75 \pm 10.47)$ were included in this study. There were no differences between treatment groups in terms of age and gender (Table 1). There were no statistically significant differences between Biofreeze and superficial heat group for all of the four parameters (VAS, OHIP-14, the unassisted (mandibular) opening without pain, and maximum assisted (mandibular) opening) (Table 2). However, the favorable effects of both applications on these four parameters continued only during the usage periods ( $p<0.001$, observed power $=1.000$ ).

For each treatment group, a significant difference between the unassisted (mandibular) opening without pain, maximum assisted (mandibular) opening, VAS, and OHIP-14 scores, and usage periods was observed (Table 3 ).

Table 1. Comparison of the two groups in terms of age and gender. $t$-test and Fisher's exact text; sd: standard deviation; $p$ : population correlation coefficient; $n$ : sample size.

\begin{tabular}{|c|c|c|c|c|}
\hline & $\begin{array}{l}\text { Total } \\
(n=52)\end{array}$ & $\begin{array}{l}\text { Biofreeze } \\
(n=26)\end{array}$ & $\begin{array}{l}\text { Superficial } \\
\text { heat }(n=26)\end{array}$ & $\mathbf{p}$ \\
\hline $\begin{array}{l}\text { Age, mean } \\
( \pm s d)\end{array}$ & $36.75 \pm 10.47$ & $37.35 \pm 10.64$ & $36.15 \pm 10.47$ & 0.686 \\
\hline \multicolumn{5}{|c|}{ Gender, n (\%) } \\
\hline Male & $7(13.5)$ & $24(92.3)$ & $21(80.8)$ & 0.419 \\
\hline Female & $45(86.5)$ & $2(7.7)$ & 5 (19.2) & \\
\hline
\end{tabular}

On the $7^{\text {th }}$ day, the unassisted (mandibular) opening without pain and maximum assisted (mandibular) opening were statistically significant compared to baseline $(p<0.001)$. On the $21^{\text {st }}$ day, the unassisted (mandibular) opening without pain, and maximum assisted (mandibular) opening significantly reduced compared to the $7^{\text {th }}$ day after treatment, but they were not statistically significant from the baseline
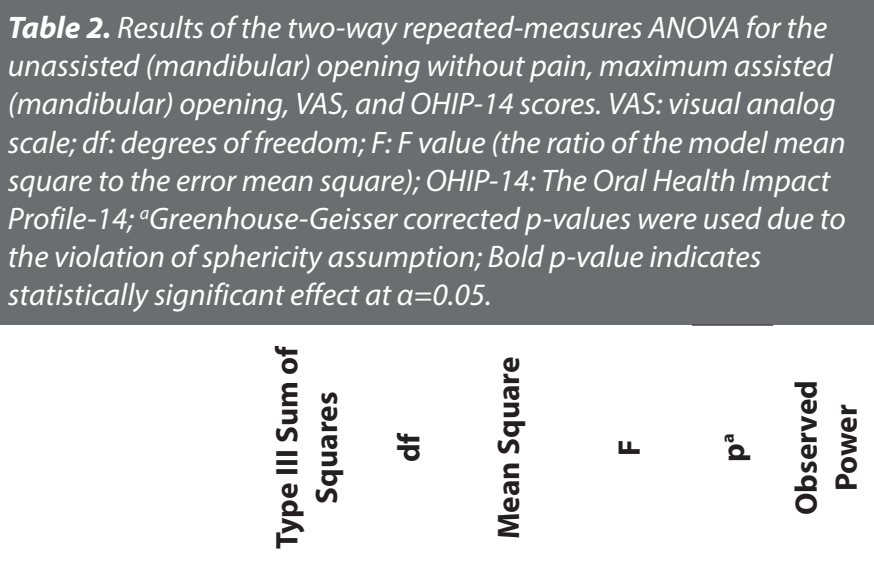

\begin{tabular}{|c|c|c|c|c|c|c|}
\hline \multicolumn{7}{|c|}{ The unassisted (mandibular) opening without pain } \\
\hline Treatment & 1.853 & 1.000 & 1.853 & 0.025 & 0.875 & 0.053 \\
\hline Time & 380.667 & 1.363 & 279.265 & 63.024 & $<0.001$ & 1.000 \\
\hline $\begin{array}{l}\text { Time } \times \text { Treatment } \\
\text { interaction }\end{array}$ & 21.128 & 1.299 & 16.262 & 2.937 & 0.087 & 0.320 \\
\hline
\end{tabular}

\begin{tabular}{lcccccc|}
\hline Maximum assisted (mandibular) opening & & & \\
\hline Treatment & 3.692 & 1.000 & 3.692 & 0.037 & 0.849 & 0.054 \\
\hline Time & 251.551 & 1.496 & 168.181 & 34.219 & $<0.001$ & 1.000 \\
\hline $\begin{array}{l}\text { Timex Treatment } \\
\text { interaction }\end{array}$ & 35.808 & 1.443 & 24.821 & 4.206 & 0.054 & 0.563 \\
\hline
\end{tabular}

$\begin{array}{lcccccc}\text { VAS } & & & & & & \\ \text { Treatment } & 20.103 & 1.000 & 20.103 & 1.578 & 0.221 & 0.227 \\ \text { Time } & 328.551 & 1.186 & 276.910 & 238.435 & <0.001 & 1.000 \\ \begin{array}{l}\text { Timex Treatment } \\ \text { interaction }\end{array} & 0.782 & 1.332 & 0.587 & 0.907 & 0.376 & 0.244\end{array}$

\begin{tabular}{lcccccc} 
OHIP-14 Score & & & & & & \\
\hline Treatment & 1.641 & 1.000 & 1.641 & 0.013 & 0.912 & 0.051 \\
\hline Time & 9520.192 & 1.209 & 7874.080 & 51.146 & $<\mathbf{0 . 0 0 1}$ & 1.000 \\
$\begin{array}{l}\text { Timex Treatment } \\
\text { interaction }\end{array}$ & 222.936 & 1.514 & 147.282 & 5.024 & $\mathbf{0 . 0 1 8}$ & 0.812 \\
\hline
\end{tabular}

Table 3. Comparison of the long and short-term effects of Biofreeze and Superficial heat groups. VAS: visual analog scale; OHIP-14: The Oral Health Impact Profile-14; $n$ : sample size; mean $\pm S D^{a, b}$ : Same superscript letters indicate a statistically significant difference between the periods based on the Bonferroni post-hoc tests.

Biofreeze $(n=26)$

Superficial heat $(n=26)$

\begin{tabular}{|c|c|c|c|c|c|c|}
\hline & Baseline & 7th day & 21 st day & Baseline & 7th day & 21 st day \\
\hline $\begin{array}{l}\text { The unassisted (mandibular) } \\
\text { opening without pain }\end{array}$ & $31.27 \pm 5.59 a$ & $35.54 \pm 5.49 a b$ & $31.65 \pm 4.95 b$ & $32.15 \pm 4.98 a$ & $34.73 \pm 4.99 a b$ & $32.23 \pm 4.95 b$ \\
\hline $\begin{array}{l}\text { Maximum assisted (mandibular) } \\
\text { opening }\end{array}$ & $35.65 \pm 6.73 a$ & $39.65 \pm 6.61 a b$ & $36.35 \pm 6.06 b$ & $36.31 \pm 5.70 a$ & $38.04 \pm 5.52 \mathrm{ab}$ & $36.38 \pm 5.68 b$ \\
\hline VAS & $6.58 \pm 2.04 a$ & $3.65 \pm 1.65 \mathrm{ab}$ & $6.62 \pm 2.04 b$ & $7.31 \pm 1.78 a$ & $4.19 \pm 1.36 \mathrm{ab}$ & $7.50 \pm 1.86 b$ \\
\hline OHIP-14 Score & $39.23 \pm 7.80 a$ & $30.35 \pm 7.40 \mathrm{ab}$ & $51.50 \pm 9.17 \mathrm{ab}$ & $41.88 \pm 9.53 a$ & $31.35 \pm 8.91 \mathrm{ab}$ & $48.46 \pm 13.32 \mathrm{ab}$ \\
\hline
\end{tabular}


values for each treatment group. After 7 days, the mouth opening increased by $4.27 \pm 3.80 \mathrm{~mm}$ in the Biofreeze group and $2.58 \pm 2.16 \mathrm{~mm}$ in the superficial heat group. In each group, a significant reduction in VAS and OHIP-14 scores was observed on the $7^{\text {th }}$ day compared to the baseline values $(p<0.001)$. Additionally, the $21^{\text {st }}$ day of VAS and OHIP14 scores increased significantly compared to the $7^{\text {th }}$ day $(p<0.001)$.

\section{Discussion}

This study represents the influence of superficial heat and Biofreeze on myofascial pain, mouth opening (measured in $\mathrm{mm}$ ), and oral health-related quality of life among patients with MPS. The prevalence of myofascial pain was predominantly identified in young women in the present study. Consistent with this result, myofascial pain has been most commonly reported among individuals aged 30-49 years and occurs twice as frequently in women as in men $(19,20)$. Ligament laxity, subluxation, posture disorders, and psychic factors are considered to serve as predisposing factors for the development of MPS (2). However, Brennum et al. (21) have postulated that women are more sensitive to pain than men, although no correlation has been found between age and pain perception. Treatment recommendations for MPS range from rest, nonsteroidal anti-inflammatory drugs (NSAIDs), and oral splints to more aggressive and irreversible treatments (22-24). Occlusal splints can change the muscle activity patterns and the positioning of the temporomandibular joint by increasing the vertical dimension of the mouth (25). Hot-cold packs and jaw exercises are considered self-care therapy, and these approaches can reduce parafunctional jaw activities, relieve pain, and improve the range of motion by relaxing the muscles (26-28). Truelove et al. (29) stated that oral splint therapy did not provide any advantage over self-care therapy, such as thermal packs, stress reduction, NSAIDs, and jaw relaxation techniques. Therefore, in the present study, we aimed to evaluate the long-term occlusal splint needs of patients who used two basic treatment approaches. Therefore, only patients with MPS who did not use occlusal splints were included in this study.

Heat application, which is preferred for the treatment of myofascial pain, increases metabolism and facilitates circulation by dilating the blood vessels, resulting in increased catabolism, the excretion of lactic acid, and the removal of uric acid and other acidic waste products from muscle cells $(30,31)$. Due to these mechanisms, heat application is thought to reduce fatigue and the signs of aging and produce an analgesic effect on the musculoskeletal system (31). The effects of heat application are not limited to the treatment of neck and back pain, with beneficial effects described for reducing knee pain, temporomandibular joint pain, and delaying exercise-related muscle pain $(6,32,33)$. Chabal et al. (34) reported that the analgesic effects of a single one 30-minute thermal application lasted for 2 hours after the application was completed. The principles of thermodynamics suggest that moist heat is more effective than dry heat due to the interactions between molecules $(34,35)$. For this reason, moist heat using a towel soaked in hot water was the preferred method used in our study, with the goal of reducing muscle tension and increasing the size of the mouth opening by providing flexibility to collagen structures, such as tendons, ligaments, joint capsules $(6,36,37)$. A previous study reported that trigger points are inactivated for up to 72 hours by the application of only moist heat, without the need for additional treatment (38). In addition, heat wraps have been found to have more effective analgesic properties than ibuprofen or acetaminophen (39). In patients with acute temporomandibular disorder, the mouth opening was increased by 3.5 to $9 \mathrm{~mm}$ following the application of superficial moist heat (6). In our study, an increase of $2.58 \pm 2.16$ $\mathrm{mm}$ was found following superficial heat application.

The use of thermotherapy for the treatment of temporomandibular disorders and neuromuscular disorders has been described in previous studies, but few studies have addressed the amount and or changes in temperature used in the methodology $(6,40-43)$. In these studies, the daily application dose and duration of the heat applications often vary $(6,40-43)$. Previous studies have indicated that pain relief was achieved with a minimum of 20 minutes of heat application (6,40-43). Based on these results, a total of 30 minutes of superficial moist heat, applied once per day, was the preferred approach used in our study, and we found significant improvements in the size of the mouth opening among patients with myofascial pain. However, the patients' acceptance of heat- or cold-based treatments for pain relief may vary. Brandt reported that $60 \%$ of participants diagnosed with rheumatoid arthritis (RA) and osteoarthritis (OA) expressed a preference for heat-based treatments for their aching joints, whereas $20 \%$ expressed a preference for cold-based applications (44). Cold-based applications exert analgesic effects by increasing the pain threshold and suppressing inflammation (45).

The primary component of the Biofreeze application used in this study is menthol. When menthol is applied to the skin, a cooling effect is mediated through TRPM8 (transient receptor potential cation channel subfamily $M$ [melastatin] member $8)$, which can prevent inflammatory pain $(46,47)$. TRPM8, also referred to as the menthol receptor, has also been detected in gingiva and incisive papilla (46-48). The wide distribution of menthol receptors throughout oral and craniofacial structures can also result in the topical analgesic effect being mediated through interactions with the dense neural network that is embedded in the dermal-epidermal junction of the skin and mucosa $(49,50)$. It acts as a dose-dependent skin vasodilator, acting through nitric oxide, RhoA/Rho-kinase, and endothelium-derived hyperpolarizing factor (EDHF)-based mechanisms, which can increase cutaneous blood flow $(51,52)$. Increasing attention has been paid to the therapeutic efficacy of menthol for the treatment of neuropathic pain syndromes, which is accompanied by hyperalgesia and allodynia (53). The current study showed an increase in the mouth opening size among patients during the Biofreeze application.

Fibromyalgia (FM) and MPS are the most common types of chronic musculoskeletal pain, reported to affect $80 \%$ of the general population (54). Whereas MPS is a regional pain condition that can be managed using conservative interventions, FM is a more complex pain condition, often requiring a multidisciplinary treatment approach, in addition to conservative measures $(55,56)$. The etiology of $F B$ is unknown, whereas MPS has been linked to local injuries and repetitive microtraumas (54). FB is classified as a chronic form of myal- 
gia and bilateral, generalized muscle tenderness that lasts at least 3 months (54). In MPS, pain can also persist for more than three months, originating from the trigger point and excessively irritable nodules that respond to palpation (54).

MPS affects the social functioning and physical/psychological health of the affected individual person and results in loss of workdays and the increased need for healthcare (57). Acute MPS is likely to be localized and can heal spontaneously or through the use of simple therapeutic strategies (heat or cold application, physical therapy, dry needling, or injection with a local anesthetic). However, MPS can also occur intermittently due to an underlying structural and environmental stimulus that cannot be corrected (58).

\section{Conclusion}

Biofreeze and superficial heat were both found to increase the quality of life, but the limited effectiveness of these applications emphasizes the importance of the underlying structural, postural, and ergonomic factors which should be treated appropriately to control myofascial pain and to prevent recurrence.

Türkçe Özet: Biofreeze ve yüzeyel ısının mastikatör miyofasiyal ağrı sendromuna (MAS) etkisi. Amaç: Bu çalısma, MAS'lı hastalarda yüzeysel ısı ve Biofreeze'in ağrı, ağız açıklı̆ı $(\mathrm{mm})$ ve yaşam kalitesi üzerindeki etkisini değerlendirmeyi amaçlamaktadır. Gereç ve Yöntem: Çalışmaya dahil edilen MAS'ı olan 52 hasta, yüzeysel ısı ve Biofreeze uygulaması yapılmak üzere rastgele iki gruba ayrıldı. Biofreeze grubundaki hastalar ( $n=26)$ günde iki kez olmak üzere yedi gün boyunca masseter ve temporal kaslarına \% 3.5 mentol jeli uygularken, diğer grup yüzeyel ısı uyguladı. Hastaların başlangıç, 7. ve 21. gün VAS, ağız açıklığı (mm) ve Ağız Sağlığı Etki Profili-14 (OHIP-14) skorları SPSS ile değerlendirildi. Bulgular: Ağız açıklığı, Biofreeze uygulanan grupta 4,27 $\pm 3,80 \mathrm{~mm}$, yüzeysel ısı uygulanan grupta 2,58 $\pm 2,16 \mathrm{~mm}$ artmıştır. Her grupta başlangıç değerlerine göre 7. günde VAS ve OHIP-14 skorlarında anlamlı azalma gözlenmiştir ( $p$ <0.001). Miyofasiyal ağrı, ağız açıklığı $(\mathrm{mm})$ ve OHIP-14 skorlarında iki uygulama arasında istatistiksel olarak anlamlı fark yoktur ( $p>0.05$ ). Her iki uygulamanın bu parametreler üzerindeki olumlu etkileri sadece kullanım süreleri ile sınırı kalmıştır. Sonuç: Bu çalışmada, Biofreeze ve yüzeysel ısının MPS'deki etkileri analiz edilmiştir. Her iki uygulamanın da yaşam kalitesini artırdığı bulunmuştur, ancak bu uygulamaların sınırlı etkinliği altta yatan faktörlerin düzeltilmesinin önemine dikkat çekmektedir. Anahtar Kelimeler: Miyofasiyal ağrı, miyofasiyal ağrı sendromları, miyofasiyal ağrı tetik noktası, mentol, yansıyan ağrı

Ethics Committee Approval: Research was approved by the Ethics Committee of the Gazi University (No:2015/118).

Informed Consent: Participants provided informed constent.

Peer-review: Externally peer-reviewed.

Author contributions: DY and CA participated in designing the study. DY and CA participated in generating the data for the study. DY and CA participated in gathering the data for the study. OK participated in the analysis of the data. DY wrote the majority of the original draft of the paper. DY and CA participated in writing the paper. DY and CA have had access to all of the raw data of the study. DY and $C A$ have reviewed the pertinent raw data on which the results and conclusions of this study are based. have DY, CA, OK approved the final version of this paper. DY guarantees that all individuals who meet the Journal's authorship criteria are included as authors of this paper.

Conflict of Interest: The authors had no conflict of interest to declare.
Financial Disclosure: The authors declared that they have received no financial support.

\section{References}

1. Okada-Ogawa A, Sekine N, Watanabe K, Kohashi R, Asano $\mathrm{S}$, Iwata K, Imamura Y. Change in muscle hardness after trigger point injection and physiotherapy for myofascial pain syndrome. J Oral Sci 2018; 17: 0453.

2. Fricton JR, Kroening R, Haley D, Siegert R. Myofascial pain syndrome of the head and neck: a review of clinical characteristics of 164 patients. Oral Surg Oral Med Oral Pathol Oral Radiol Endod 1985; 60: 615-23. [CrossRef]

3. Farina $S$, Casarotto $M$, Benelle $M$, Tinazzi $M$. A randomized controlled study on the effect of two different treatments (FREMS AND TENS) in myofascial pain syndrome. Eur J Phys Rehabil Med 2004; 40: 293.

4. Velly AM, Gornitsky M, Philippe P. Contributing factors to chronic myofascial pain: case-control study. Pain 2003; 104: 491-9. [CrossRef]

5. Wheeler AH. Myofascial pain disorders. Drugs 2004; 64: 45-62. [CrossRef]

6. Nelson SJ, dos Santos J, Barghi N, Narendran S. Using moist heat to treat acute temporomandibular muscle pain dysfunction. Compendium (Newtown, Pa.) 1991; 12: 808-10.

7. Reiter S, Goldsmith C, Emodi-Perlman A, Friedman-Rubin P, Winocur E. Masticatory muscle disorders diagnostic criteria: the American Academy of Orofacial Pain versus the research diagnostic criteria/temporomandibular disorders (RDC/TMD). J Oral Rehabil 2012; 39: 941-47. [CrossRef]

8. Koppert W, Frötsch K, Huzurudin N, Böswald W, Griessinger N, Weisbach $V$, et al. The effects of paracetamol and parecoxib on kidney function in elderly patients undergoing orthopedic surgery. Anesth Analg 2006; 103: 1170-6. [CrossRef]

9. McCurdy CR, Scully SS. Analgesic substances derived from natural products (natureceuticals). Life Sci 2005; 78: 476-84.

10. Knowlton WM, Daniels RL, Palkar R, McCoy DD, McKemy DD. Pharmacological blockade of TRPM8 ion channels alters cold and cold pain responses in mice. Plos one 2011; 6: e25894.

11. Hensel $H$, Zotterman $Y$. The effect of menthol on the thermoreceptors. Acta Physiol Scand 1951; 24: 27-34. [CrossRef]

12. Gaudioso C, Hao J, Martin-Eauclaire MF, Gabriac M, Delmas P. Menthol pain relief through cumulative inactivation of voltagegated sodium channels. Pain 2012; 153: 473-84. [CrossRef]

13. Olive $\mathrm{JL}$, Hollis B, Mattson E, Topp R. Vascular conductance is reduced after menthol or cold application. Clin J Sport Med 2010; 20: 372-6.

14. Richter M. The Effects of Biofreeze on Cutaneous Blood Flow in Normal Subjects as Measured by Doppler Ultrasound.

15. Robinson SB, Kesick CM, Kolka MA, Stephenson LA. Topical Nitroglycerin Ointment (2\%) Applied to Forearm Skin Increases Skin Blood Flow. USARIEM 2001.

16. Locker D, Jokovic A, Clarke M. Assessing the responsiveness of measures of oral health-related quality of life. Community Dent Oral Epidemiol 2004; 32: 10-8.

17. Balci N, Alkan N, Gurgan CA. Psychometric properties of a Turkish version of the oral health impact profile14. Niger J Clin Pract 2017; 20: 19-24.

18. Faul F, Erdfelder E, Buchner A, Lang AG. Statistical power analyses using $\mathrm{G}^{*}$ Power 3.1: Tests for correlation and regression analyses. Behav Res Methods 2009; 41: 1149-60. [CrossRef]

19. Han SC, Harrison P. Myofascial pain syndrome and trigger-point management. Reg Anesth Pain Med 1997; 22: 89-101. [CrossRef]

20. Fricton JR. Clinical care for myofascial pain. Dent Clin North Am 1991; 35: 1-28.

21. Brennum J, Kjeldsen M, Jensen K, Jensen TS. Measurements of human pressure-pain thresholds on fingers and toes. Pain 1989; 38: $211-17$ 
22. Dionne RA. Pharmacologic treatments for temporomandibular disorders. Oral Surg Oral Med Oral Pathol Oral Radiol Endod 1997; 83: 134-42. [CrossRef]

23. Feine JS, Widmer CG, Lund JP. Physical therapy: a critique. Oral Surg Oral Med Oral Pathol Oral Radiol Endod 1997; 83: 123-7. [CrossRef]

24. Ekberg E, Vallon D, Nilner M. Occlusal appliance therapy in patients with temporomandibular disorders: a double-blind controlled study in a short-term perspective. Acta Odontol Scand 1998; 56: 122-8. [CrossRef]

25. van Grootel RJ, Buchner R, Wismeijer D, van der Glas HW. Towards an optimal therapy strategy for myogenous TMD, physiotherapy compared with occlusal splint therapy in an RCT with therapyand-patient-specific treatment durations. BMC Musculoskelet Disord 2017; 18: 1-17.

26. Burgess JA, Sommers EE, Truelove EL, Dworkin SF. Short-term effect of two therapeutic methods on myofascial pain and dysfunction of the masticatory system. J Prosthet Dent 1988; 60: 606-10. [CrossRef]

27. Dworkin SF, Turner JA, Wilson L, Massoth D, Whitney C, Huggins $\mathrm{KH}$, et al. Brief group cognitive-behavioral intervention for temporomandibular disorders. Pain 1994; 59: 175-87. [CrossRef]

28. Dworkin SF, Huggins KH, Wilson L, Mancl L, Turner J, Massoth $\mathrm{D}$, et al. A randomized clinical trial using research diagnostic criteria for temporomandibular disorders-axis II to target clinic cases for a tailored self-care TMD treatment program. J Orofac Pain 2002;16.

29. Truelove E, Huggins KH, Mancl L, Dworkin SF. The efficacy of traditional, low-cost and nonsplint therapies for temporomandibular disorder: a randomized controlled trial. J Am Dent Assoc 2006; 137: 1099-1107.

30. Simons DG, Travel JG, Simons LS. Travell \& Simons' myofascial pain and dysfunction: upper half of body. Lippincott williams \& wilkins, 1999.

31. Kojima A, Goto K, Morioka S, Naito T, Akema T, Fujiya H, et al. Heat stress facilitates the regeneration of injured skeletal muscle in rats. J Orthop Sci 2007; 12: 74-82. [CrossRef]

32. Petrofsky JS, Laymon MS, Alshammari FS, Lee H. Use of low level of continuous heat as an adjunct to physical therapy improves knee pain recovery and the compliance for home exercise in patients with chronic knee pain: A randomized controlled trial. J Strength Cond Res 2016; 30: 3107-15. [CrossRef]

33. Petrofsky J, Berk L, Bains G, Khowailed IA, Lee H, Laymon M. The efficacy of sustained heat treatment on delayed-onset muscle soreness. Clin J Sport Med 2017; 27: 329-37. [CrossRef]

34. Chabal C, Dunbar PJ, Painter I, Young D, Chabal DC. Properties of Thermal Analgesia in a Human Chronic Low Back Pain Model. J Pain Res 2020; 13: 2083. [CrossRef]

35. Poindexter RH, Wright EF, Murchison DF. Comparison of moist and dry heat penetration through orofacial tissues. CRANIO 2002; 20: 28-33. [CrossRef]

36. De Laat A, Stappaerts K, Papy S. Counseling and physical therapy as treatment for myofascial pain of the masticatory system. J Orofac Pain 2003; 17.

37. Nadler SF, Steiner DJ, Erasala GN, Hengehold DA, Abeln SB, Weingand KW. Continuous low-level heatwrap therapy for treating acute nonspecific low back pain. Arch Phys Med Rehabil 2003; 84: 329-34. [CrossRef]

38. Nadler SF, Steiner DJ, Petty SR, Erasala GN, Hengehold DA, Weingand KW. Overnight use of continuous low-level heatwrap therapy for relief of low back pain. Arch Phys Med Rehabil 2003; 84: 335-42. [CrossRef]

39. Nadler SF, Steiner DJ, Erasala GN, Hengehold DA, Hinkle RT, Goodale MB, et al. Continuous low-level heat wrap therapy provides more efficacy than Ibuprofen and acetaminophen for acute low back pain. Spine 2002; 27: 1012-17. [CrossRef]
40. Nelson SJ, Ash Jr M. An evaluation of a moist heating pad for the treatment of TMJ/muscle pain dysfunction. CRANIO 1988; 6: 355-9.

41. de Felício CM, Freitas RL, Bataglion C. The effects of orofacial myofunctional therapy combined with an occlusal splint on signs and symptoms in a man with TMD-hypermobility: case study. IJOM 2007; 33: 21-9.

42. Dıraçoğlu D, Saral İB, Keklik B, Kurt H, Emekli U, Özçakar L, et al. Arthrocentesis versus nonsurgical methods in the treatment of temporomandibular disc displacement without reduction. Oral Surg Oral Med Oral Pathol Oral Radiol Endod 2009; 108: 3-8. [CrossRef]

43. Nozaki S, Kawai M, Shimoyama R, Futamura N, Matsumura $T$, Adachi K, et al. Range of motion exercise of temporo-mandibular joint with hot pack increases occlusal force in patients with Duchenne muscular dystrophy. Acta Myol 2010; 29: 392.

44. Brandt KD. The importance of nonpharmacologic approaches in management of osteoarthritis. Am J Med 1998; 105: 39-44.

45. Algafly AA, George KP. The effect of cryotherapy on nerve conduction velocity, pain threshold and pain tolerance. $\mathrm{Br}$ J Sports Med 2007; 41: 365-9.

46. Ferrandiz-Huertas C, Mathivanan S, Wolf CJ, Devesa I, FerrerMontiel A. Trafficking of thermoTRP channels. Membranes 2014; 4: 525-564. [CrossRef]

47. Liu B, Fan L, Balakrishna S, Sui A, Morris JB, Jordt SE. TRPM8 is the principal mediator of menthol-induced analgesia of acute and inflammatory pain. PAIN 2013; 154: 2169-77. [CrossRef]

48. Yajima T, Sato T, Hosokawa H, Kondo T, Saito M, Shimauchi $H$, et al. Distribution of transient receptor potential melastatin-8containing nerve fibers in rat oral and craniofacial structures. Ann Anat 2015; 201: 1-5. [CrossRef]

49. Finch PM, Drummond PD. Topical treatment in pain medicine: from ancient remedies to modern usage Pain Manag 2015; 5: 359-71.

50. Cliff MA, Green BG. Sensory irritation and coolness produced by menthol: evidence for selective desensitization of irritation. Physiol Behav 1994; 56: 1021-29. [CrossRef]

51. Sun J, Yang T, Wang P, Ma S, Zhu Z, Pu Y, et al. Activation of cold-sensing transient receptor potential melastatin subtype 8 antagonizes vasoconstriction and hypertension through attenuating RhoA/Rho kinase pathway. Hypertension 2014; 63: 1354-63. [CrossRef]

52. Craighead DH, Alexander LM. Topical menthol increases cutaneous blood flow. Microvasc Res 2016; 107: 39-45. [CrossRef]

53. Andersen HH, Olsen RV, Møller HG, Eskelund PW, Gazerani $P$, Arendt-Nielsen L. A review of topical high-concentration L-menthol as a translational model of cold allodynia and hyperalgesia. Eur J Pain 2014; 18: 315-25. [CrossRef]

54. Bourgaize S, Newton G, Kumbhare D, Srbely J. A comparison of the clinical manifestation and pathophysiology of myofascial pain syndrome and fibromyalgia: implications for differential diagnosis and management. J Can Chiropr Assoc 2018; 62: 26.

55. Borg-Stein J, laccarino MA. Myofascial pain syndrome treatments. Phys Med Rehabil Clin N Am 2014; 25: 357-74. [CrossRef]

56. Leventhal LJ. Management of fibromyalgia. Ann Intern Med 1999; 131: 850-858. [CrossRef]

57. Sprangers MA, de Regt EB, Andries F, van Agt HM, Bijl RV, de Boer $\mathrm{JB}$, et al. Which chronic conditions are associated with better or poorer quality of life? J Clin Epidemiol 2000; 53: 895-907.

58. Gerwin RD. Classification, epidemiology, and natural history of myofascial pain syndrome. Curr Pain Headache Rep 2001; 5: 41220. [CrossRef] 